\title{
ENHANCING CRITICAL THINKING SKILLS OF FUTURE LANGUAGE SCHOLARS IN PEDAGOGICAL COURSES
}

\author{
Liliya Baranovska \\ National Aviation University, Ukraine \\ liliya03.05@ukr.net \\ Liliya Morska \\ The University of Bielsko-Biala, Bielsko-Biala, Poland \\ liliya.morska@gmail.com \\ Iryna Simkova \\ isimkova@ukr.net
}

National Technical University of Ukraine "Igor Sikorsky Kyiv Polytechnic Institute”, Ukraine

\author{
Alla Zasluzhena \\ National Aviation University, Ukraine \\ allabox1303@gmail.com
}

\begin{abstract}
The paper reports on the results of critical thinking enhancement during the training of future language scholars in a Comparative Pedagogy course. 61 future language scholars from Poland and Ukraine took part in the research. The mixed research was based on the qualitative and quantitative analysis of students' responses regarding critical thinking enhancement after completing the course. Informal interviews and diagnostic tests were used. For the verification of results, we applied Fisher's Exact Variance Test (F-test). The results show that most respondents (91\%) enhanced their skills and abilities in critical thinking: differentiating information (76\%), categorising information (62\%), comparing information (85\%), estimating information (87\%), analysing and synthesising information $(91 \%)$. The findings of this study support the idea that students' critical thinking skills can be successfully developed in pedagogical courses.
\end{abstract}

Keywords: critical thinking; comparative pedagogy; future language scholars; Polish universities; professional training; Ukrainian universities.

\section{Introduction}

The training of highly qualified language scholars is widely considered to be the most important issue nowadays. Modern society requires graduates who possess high competence, creativity, and critical thinking. The process of improving the training of future language scholars within the modern higher schools of Ukraine is quite challenging due to many factors. This paper attracts attention to critical thinking development as one of the key skills in the $21^{\text {st }}$ century (Preparing 21st Century Students for a Global Society, 2016).

In this study, the course of Comparative Pedagogy is considered as a field where creativity and critical thinking has many applications. Previous works (Kuchay, 2016; Zasluzhena, 2016) has been limited to the comparative analysis of foreign and native experience in higher education. Although we believe that regarding higher education, the results of effective use of the positive experience of other countries are important, until now, this methodology has only been applied in theoretical disciplines, where cultural, economic, and social differences of foreign countries are compared. This paper investigates the ways of critical thinking enhancement during the training of future language scholars in the Comparative Pedagogy course.

In the history of Comparative Education (CE), scientists (Wolhuter et al 2008) distinguish five stages of its development: 1) early stage (1900s - 1910s); 2) classic stage (1920s - 1930s); 3) expansion stage (1950s - mid-1970s); 4) varied trends stage (mid-1970s - 1990s); 5) new development stage (2000s).

Manzon (2011) emphasises that CE encompasses not only the study of foreign education systems but first and foremost, the national education system, this statement illustrates the value of comparison in education: in knowing 'the Other', one can know oneself better.

In the cutting edge paper of 1981, Stone has regarded the CE from a threefold perspective: an education systems perspective (CE focuses on education systems, rather than on individual educator-educed dynamics); a social perspective (CE focuses on the interrelationships between social for example societal, political,

Baranovska, L., Morska, L., Simkova, I., \& Zasluzhena, A. (2020). Enhancing critical thinking skills of future language scholars in pedagogical courses. Advanced education, 14, 91-99. https://doi.org/10.20535/2410-8286.202382 
economic, geographic, demographic, and religious-philosophical context and education); a comparative perspective (CE focuses on the comparison of different education systems within their societal contexts).

The last four years have witnessed that the potential of $\mathrm{CE}$ has been recognised all over the world (Baranovska and Zasluzhena, 2015; Sysoieva, 2008). CE has received much attention not only as an essential mechanism for determining the efficacy of an education system and the ways of its improvement, but as a powerful tool for $21^{\text {st }}$-century skills development.

Wolhuter (2016) reported that about 38 countries proposed a course of CE at the Undergraduate level (Bachelor's degree) and about 24 countries at the Graduate level (Master's degree). We agree with Wolhuter (2016) that CE provides a description of learning communities within their societal contexts in order to satisfy the need for knowledge, which is a unique part of human nature. In addition, Wolhuter (2016) mentioned the application of CE in educational planning and reform; in teaching practice; in other fields of Educational study, e.g. the Philosophy of Education. Our study proposes to expand the applied aspects of CE because critical thinking, analysis and synthesis skills, ability to differentiate, categorise, compare, estimate, and order are important for the implementation of the CE tasks as well as theoretical, descriptive, and systematic approaches.

Critical thinking is one of the main factors in the progressive development of society and a means of improving social forms, institutions and values. A recent review of the literature on this topic found out that the pedagogical problem of critical thinking development is poorly investigated. The analysis of studies on this issue showed that the problem of critical thinking was studied by experts (Evens et al., 2014; Carol et al., 2004; Bowell and Kemp, 2010). However, modern authors have pointed out the need for a theoretical and practical solution to the problem of critical thinking development in professionals training (Morska, 2018; Belghiti et al., 2017; Samoilov, 2014).

Changing social and economic guidelines in the development of society, and the dynamism of progressive changes led to the emergence of a situation of uncertainty. It determines the need to evaluate and significantly increased the role of the individual as a subject of social evolution. The solution of a given problem can be found in the ability to assess the existing situation based on its critical analysis.

Some aspects of the development of critical thinking are described in the works by Simkova and Tuliakova (2020), Solodikhina (2019), Zapalska et al. (2018). Some preliminary work (Ennis, 2015; Facione, 1990) was carried out in the early 1990s indicated that the problem of the critical thinking development was not considered in practical terms, although we can consider the theory of problem-based learning as the pedagogical basis for its solution in modern society (Rutherford, 2019).

The authors of the paper come to the conclusion that critical thinking is a guarantee of public health because it represents a means of protecting society from unreasonable reform models. So, the aim of our study is to broaden current knowledge about the ways of critical thinking enhancement during the future language scholars training in CE, namely Comparative pedagogy. For this purpose, we will examine the challenges of teaching comparative pedagogy in Ukraine; implement the activities aimed at enhancing students' critical thinking into the Comparative pedagogy course; interview future language scholars who participated in the experimental study from Polish and Ukrainian universities; validate finding regarding critical thinking enhancement during the teaching of future language scholars.

\section{Methods}

\section{General Background of Research}

To achieve the goals of the study, a complex of interrelated methods of scientific research has been used. The main theoretical methods used in the study are the comparative analysis of the specificities of future language scholars training in European Union (namely, Poland) and Ukrainian universities. The additional theoretical methods have been used in the study are the terminological analysis to define the key concepts of a comparative pedagogy; the chronological and causal analysis to explore the problem of the formation of a comparative pedagogy as a science and discipline, to highlight the main results of comparative studies made by researchers; the content analysis of the curriculum of future language scholars in Poland and Ukraine to determine the specificities of their training.

The empirical methods used in the study are the quantitative and qualitative analysis of interviews with Ukrainian students; Fisher's Exact Variance Test (F-test) for verification of results. The interviews were performed in two stages. The experimental study consists of three stages. On the first stage, the interviews with future language scholars were conducted before the training in Comparative Pedagogy course. The second stage deals with the implementation of the Comparative Pedagogy course. On the third stage, the interviews with future language scholars were conducted after they completed Comparative Pedagogy course. 
Data received during the interviews are based on the student's personal feelings and personal selfevaluation. To be more precise about their personal feeling concerning the critical thinking skills enhancement we proposed students to pass one of the following tests: The California Critical Thinking Dispositions Inventory (1992) was developed by Peter Facione and N. C. Facione, The Ennis-Weir Critical Thinking Essay Test (1985) was developed by Robert H. Ennis and Eric Weir, and The Watson-Glaser Critical Thinking Appraisal (1980) offered through Harcourt Assessment, Inc. Generally speaking, there are a lot of different tests for critical thinking assessment but listed above being regarded as among the more reliable (Matthews \& Lally, 2010).

\section{Participants}

The criterion for selecting participants was their training in the Comparative pedagogy course. The study was carried out among 61 future language scholars from Poland and Ukraine (University of BielskoBiala, Bielsko-Biala: 31 participants (Poland); National Aviation University, Kyiv, Ukraine; Yuriy Fedkovych Chernivtsi National University, Ukraine: 30 participants) of 18 to 23 years old.

They were divided into four groups of students (TG-1, TG-2, TG-3, and TG-4) that were of similar size (about 15 students). Two testing groups of future language scholars from Ukraine and two testing groups of future language scholars from Poland participated in the training where instructors gave special attention to critical thinking skills development. All participants from four groups were recruited for the interview before and after completion of training in comparative pedagogy. Interviews were carried out informally.

\section{Instrument and Procedures}

To verify the interview results of the critical thinking enhancement of the future language scholars during the Comparative Pedagogy course, Fisher's Exact Variance Test (F-test) was used. Data management was performed with XLSTAT by Addinsoft. The F-test was chosen because it is one of the most feasible ways to verify the positive effects of the critical thinking enhancement of future language scholars during the Comparative Pedagogy course.

Table 1 presents the initial data for the application of the F-test. It contains the interview results received from students before and after the training in comparative pedagogy where instructors gave special attention to critical thinking skills development. We consider the results given by students in testing groups (TG-1, TG-2, TG-3, and TG-4) before they complete the Comparative Pedagogy course to be sample 1, and results presented by students after they completed the Comparative Pedagogy course to be sample 2 .

During the first phase, we have formulated statistical hypotheses that enable the calculation of the results received before and after the completion of the Comparative Pedagogy course. The statistical hypotheses assume the null $(\mathrm{H} 0)$ and alternative $(\mathrm{Ha})$ hypotheses. H0: the results presented in sample 1 showed that the number of students who enhanced their critical thinking skills before the completion of Comparative Pedagogy course is higher than the number of students, who enhanced their critical thinking skills after the completion of Comparative Pedagogy course (sample 2); Ha: the results presented in sample 1 showed that the number of students who enhanced their critical thinking skills before the completion of Comparative Pedagogy course is lower or equal to the number of students, who enhanced their critical thinking skills after the completion of Comparative Pedagogy course (sample 2).

After the calculations have been carried out, we can see only five students consider that they enhanced their critical thinking skills before the completion of the Comparative Pedagogy course. So, we put 5 to the first higher column (quantity of students - before). Fifty-six students who enhanced their critical thinking skills after the completion of the Comparative Pedagogy course. So, we put 56 to the lower column (quantity of students - after).

To define Fisher's Exact Variance Test, we use Equation (1):

where $\varphi$ - central angel value,

$$
\varphi=2 \arcsin \sqrt{ } p
$$

$\mathrm{p}$ - percentage value.

$$
\begin{aligned}
& \varphi^{*} 1=2 \arcsin \frac{\sqrt{5}}{61}=0,18 \\
& \varphi^{*} 2=2 \arcsin \frac{\sqrt{56}}{61}=2,53
\end{aligned}
$$

Using Equation (2) we can find the empirical F-test $\varphi^{*}$ emp:

$$
\varphi^{*} \mathrm{emp}=\left(\varphi^{*} \max -\varphi^{*} \min \right) \sqrt{ } \frac{\mathrm{n} 1 \cdot \mathrm{n} 2}{\mathrm{n} 1+\mathrm{n} 2}
$$


In Equation (2):

$\varphi^{*} \max$ stands for angle corresponding to bigger percentage,

$\varphi^{*}$ min stands for angle corresponding to smaller percentage,

n1 stands for quantity of students in sample 1 ,

$\mathrm{n} 2$ stands for quantity of students in sample 2 .

In our study

$$
\varphi^{*} \mathrm{emp}=(2,53-0,18) \sqrt{ } \frac{61 \cdot 61}{61+61}=12,9
$$

In the table for F-test variances we can find critical values of F-test (3)

\section{Results}

$$
\varphi^{*} \text { crit }=\left\{\begin{array}{c}
1,64(\mathrm{p} \geqslant 0,05) \\
2,31(\mathrm{p} \geqslant 0,01)
\end{array}\right.
$$

As was stated before most respondents (56 students) commented that after the completion of the Comparative Pedagogy course they enhanced their skills and abilities in critical thinking. In Table 1 we divided the empirical frequencies of students' samples in compliance with two variances: "Effect present" and "Effect absent".

Table 1. The results of empirical frequencies of the sample

\begin{tabular}{|c|c|c|c|c|c|}
\hline \multirow{2}{*}{ RESULTS } & \multicolumn{3}{|c|}{ «Effect present» } & «Effect absent» & $\begin{array}{c}\text { The total } \\
\text { quantity of } \\
\text { students }\end{array}$ \\
\cline { 2 - 6 } SAMPLES & $\begin{array}{c}\text { Quantity of } \\
\text { students }\end{array}$ & $\%$ & $\varphi$ & Quantity of students & 61 \\
\hline Sample 1 & 5 & $9 \%$ & 0,18 & 56 & 61 \\
\hline Sample 2 & 56 & $91 \%$ & 2,53 & 5 & \\
\hline
\end{tabular}

Our comparison of the critical value results with the empirical value results can be demonstrated in Fig. 1 with the help of the axe of significant zones.

$$
\begin{aligned}
\varphi^{*} \text { crit }(0,01) & <\varphi^{*} \text { emp } \\
2,53 & <12,9
\end{aligned}
$$

Insignificant Zone

Significant Zone

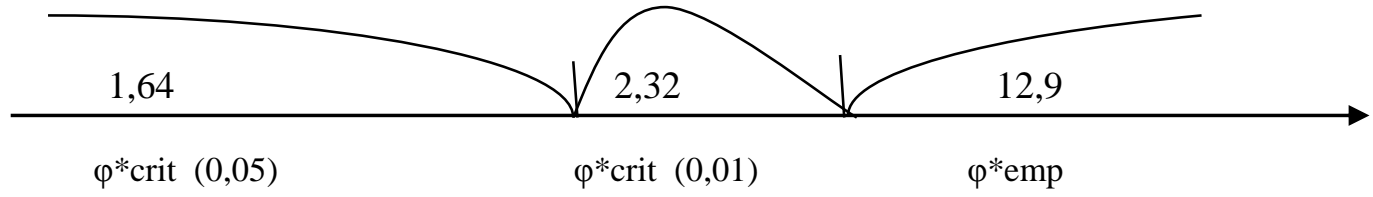

Figure 1. Graphical F-test presentation with Significant and Insignificant zones

Our empirical value belongs to the Significant Zone of F-test that is why the results are significant. Figure 1 stipulates we adopt alternative hypothesis where the results presented in sample 1 (before the training) and 2 (after the training) stipulate that quantity of students who enhanced their critical thinking skills before the completion of Comparative Pedagogy course are lower or equal to the number of students, who enhanced their critical thinking skills after the completion of Comparative pedagogy course.

Therefore, the majority of respondents before the completion of Comparative pedagogy felt that the level of their critical thinking skills is low. At the same time, only five per cent of those interviewed assessed that the level of their critical thinking skills is high. Approximately two-thirds of the participants from Poland (61\%) said that they chose the Comparative Pedagogy course, not because of critical thinking skills enhancement, but in order to get knowledge about the history of pedagogy. Just a small number of interviewed in Ukraine (17\%) could make a logical connection between comparative pedagogy and critical thinking skills enhancement.

As we assumed, the most marked observation to emerge from the data obtained was that almost all (91\%) future language scholars from Ukraine and Poland who participated in the training where the critical thinking skills development were given special attention positively evaluate the course design. 
The 50 subjects of those who took part in the interview felt enthusiastic about tasks aimed at critical thinking enhancement during the Comparative Pedagogy course. When the subjects in Poland and Ukraine were asked about specific abilities and skills improved, the majority mentioned the enhancement in the ability to differentiate information (76\%), categorise information $(62 \%)$, compare information (85\%), estimate information (87\%). The most remarkable result to emerge from the data based on students' personal self-evaluation is that $91 \%$ of students enhanced their skills in analysis and synthesis.

\section{Discussion}

Challenges of Comparative Pedagogy training in Ukraine

The review of the sources on comparative education on the international level shows that they don't have systematised research on the problems of comparative pedagogy elaborated by the Ukrainian scholars. In our opinion, it is due to the fact that Ukraine is actively involved in the European Higher Education Area, intensively integrating into the world educational and scientific community.

A lot of attention was paid to the study of various aspects of training (development of emotional intelligence and creativity of language scholars, internationalisation of education etc.) in the United States and Canada. Individual studies have been conducted concerning China, Mexico, Australia, and Japan. The number of systematic studies in relation to professional training in general in the European Union, Western Europe, Eastern Europe, and others were substantially less (Sysoieva, 2008). However, during the last decade, there have appeared the researches on the comparative pedagogy of a systemic nature performed by the prominent Ukrainian scientists (Sysoieva 2008).

Joining the Bologna Process, intentions to integrate into the European Higher Education Area, the necessity to develop a national qualifications framework at various stages have facilitated the need to investigate foreign experience in professional training (Sysoieva 2008). Ukrainian scientists examined the professional development of secondary school teachers in continuing teaching education systems of the United Kingdom, Canada, and USA (Mukan, 2011), the training of future teachers of primary school in higher educational institutions of Poland by means of multimedia technologies (Kuchai, 2016), etc.

The interest of Ukrainian scientists to the problems of CE is due to the deepening of globalisation processes, European integration and informatisation of society, which have led to the need for modernisation of higher education. In Ukrainian higher schools where training in comparative pedagogy is provided, students use course textbooks written by native academic staff members who have experience in comparative research work. A key problem with much of the literature regarding comparative pedagogy is that too much attention is given to theoretical aspects. For instance, Vasyliuk (2011) suggests that the main purpose of training in comparative pedagogy is to reveal the issues of the historical development of comparative pedagogy as a science, the problems of determinism in the educational processes because of economic, political and social factors; representation of structural and content peculiarities of educational systems of European countries and other regions.

Our paper suggests a more practical approach to future language scholar training in comparative pedagogy that is more innovative. A good example is how Venn diagrams can be used to represent the four categorical form statements, A-, E-, I-, and O-forms, and other assignments proposed by Cohen (2009). Fig. 2 illustrates the examples of assignments that the authors of this study propose to future language scholars during training in comparative pedagogy.

\section{TESTIMONIALS}

1.1 Provide an example of an online item that is supposed to be informative in some way (for example, it gives advice or makes factual claims) but is not, in your point of view, from a reliable source - that is, a trustworthy author or website. Explain why you believe the source should not be trusted.

1.2 Provide an example of an online item that is, in your estimation, from a reliable source. Explain why the source should be trusted.

INDUCTIVE HYPOTHESIS

For each of the following sets of facts $f$, (1) formulate a relevant hypothesis $h$ that is confirmed by f, and (2) construct the hypothetical syllogism that confirms h. In some cases, you might consider researching the matter (for instance, in the Internet) before formulating your hypothesis.

1 In the United States, the global educational space is becoming a reality due to globalisation processes.

2 Sarah has found out that in foreign sources, the term "Comparative Education" is used more often than the term "Comparative Pedagogy".

3 You receive an e-mail message from "the mail administrator" saying that your e-mail account is about to be terminated unless you go to a certain website and enter your password and username to confirm your user information.

\section{Figure 2. The examples of students' assignment to enhance critical thinking during the Comparative} Pedagogy course 
As far as Comparative pedagogy is one of the youngest branches of pedagogical science in Ukraine, it is at the stage of formation, and therefore there is a wide range of directions for its further development.

Thus, comparative pedagogy contributes not only to the study of the positive experience of the countries of the world with regard to organising, selecting the content of training, its methodological support and implementation of this experience in the native educational system in order to improve the quality of education, but to the development of such skills as deductive reasoning, generalisation, prediction, causation, etc.

\section{Comparative Pedagogy courses in Poland and Ukraine}

Modern Ukrainian society has chosen the European vector of development. Consequently, this vector increases the need in the development of $21^{\text {st }}$ century skills and interest in studying the progressive experience of developed European countries. Higher education in Poland is characterised by a multicultural approach and high quality, which is stipulated by the language policy of the state, high level of its socioeconomic development, active international cooperation of its universities under the Erasmus programmes, initiative participation of Polish universities in international academic and research networking.

Regarding learning professional subjects, students gradually take responsibility for their own learning. Students use The European Language Portfolio (ELP), which is an instrument of promoting multilingual and multicultural approaches, reflecting the Council of Europe's position on creating conditions for the development of cultures and their coexistence (Radchenko, 2014).

Hutterli (2012) also supports the significance of ELP. It can be used as a diagnostic tool because it essentially provides information about the learner's intercultural and language learning experience as well as about the progressive development of hislher competences. The ELP, for instance, was expressly created to be introduced in the last year of primary school level and to be carried forward to lower secondary education. It is essential that the portfolio aspect of this instrument is taken seriously by the teachers of the following school level and that the students can use it to present their previous progress. Thus, our study pays attention to the results received from the portfolio analysis of some Polish students.

The Polish experience in future language scholars training is significant for improving training at the universities of Ukraine; it will help to successfully harmonise the national space of higher education with the European Higher Education Area.

The analysis of language scholar training in Ukraine and Poland and the concept of $21^{\text {st }}$ century skills development will enhance the rational selection of the most expedient components of training and its implementation in the pedagogical system of education and upbringing of the personality of language scholars at Ukrainian universities.

\section{Reform of higher education}

In both countries, from the end of the XX - the beginning of the XXI centuries, there was a reform in the higher education system, which affected language scholar training. The key aspects in reforming of higher education in Poland and Ukraine provide future language scholars with learning outcomes, the documents defining the process of developing National Frame of Qualification, a website for familiarising with the National system of qualifications, the requirements for quality control, additional guidance on the external quality assurance of the education system, opportunities for continuing professional development, etc.

It should be noted that in both countries learning outcomes are designed for every content component in a Comparative pedagogy course. As for critical thinking development possibilities in Poland, there are a lot of available courses of advanced studies differed by problems and vary from one-day courses to long-term programmes (up to 60 credits). The work experience and the results of the non-formal learning of students are also taken into consideration. Ukrainian universities offer syllabi and special programmes for distance learning and extramural education. In both countries, there are possibilities for language scholar's continuous education.

Thus, we state that the reform of higher education in Poland and Ukraine is generally focused on improving the quality of student training, creating conditions for continuous professional development. There are some differences regarding the structure of the system of continuous professional development: it is less standardised in Poland than in Ukraine and can become an element of implementation.

\section{Challenges of critical thinking development in Ukraine}

The lack of researches in the holistic concept for critical thinking enhancement in universities complicates critical thinking development of future language scholars, the development of their professional personalities in higher schools of Ukraine.

The education of students in comprehensive schools is often formal. In many cases, students suffer from information overload in studying professional disciplines, and there is a clear underestimation of the role of 
the humanities and pedagogy. The development of critical thinking is partially carried out in the teaching of natural sciences using new technologies (Matthews, 2010). The potential of the social and humanitarian disciplines, primarily pedagogy, is clearly not realised in this regard (Education for Life and Work..., 2012). In most cases, teaching of comparative pedagogy universities is not supported by methodological developments aimed at the development of thinking in general and critical thinking, in particular.

In recent years the theoretical development of the problem of critical thinking training in the process of teaching students in Ukraine has not been a subject of scientific research. In our opinion, the axiomatic approach to the assimilation of knowledge acquired by students, the teacher-centred approach, and the lowtech approach in the classroom influence the lack of demand for a critical style of thinking in the context of the modern system of education.

In Polish universities, the future language scholars study theoretical and applied subjects, and they possess skills of critical evaluation, methods and heuristic tools for analysing texts of different genres and periods. They are graduates with highly developed skills in English (listening, reading, spoken interaction, speech production, and writing), who meet the requirements of level C1 defined by CEFRL. They develop their knowledge, skills, and abilities in reading literary works of different periods, in conducting discussions in English on a wide range of literary subjects, which can testify the ability to make a clear and reasonable point of view (the critical approach to information processing). They increase the level of knowledge, skills, and abilities in conducting scientific research in the specialism, in mastering all English language skills from level $\mathrm{B} 1$ to $\mathrm{C} 1 / \mathrm{C} 2$, and in increasing of the awareness in English language and culture of representatives from different countries. Many Polish universities reached the conclusion that nowadays the most information is readily available and can be found by students at any time, in such a way, there is no need for teachers to present typical lectures. Thereat, the assignments of future languages scholars deal with analysis, synthesis, interpretation, and estimation of information rather than the pure presentation of information from teachers' lectures.

In Polish higher schools, an important criterion for the conceptual understanding of the specificities of training of future language scholars is content-based study. Bransford et al. (2000) admits that knowledge is better assimilated if the content of discipline is studied deeply. Future language scholars training is represented by a block of disciplines that provide specialisation in English (Linguistics) and a block of disciplines providing specialisation in the English literature.

It should be emphasised that philologists of English at Polish universities do not study native language or literature by themselves, but if they study, then in the context of comparing it with another language (for example, when acquiring a second foreign language).

An analysis of the curriculum for future language scholars in Ukraine has revealed that knowledge in the Ukrainian language is deepened and generalised during the training; courses on English Teaching Methodology, a second foreign language, and disciplines connected with English language proficiency are available. It is obvious that the theoretical training of future language scholars is also defined by the disciplines, which are not aimed at innovative skills development (for example, $4 \mathrm{Cs}$ ). The aim of higher education in Ukraine is to prepare students for successful professional activity in the future, and therefore a lot of higher schools develop in their graduates the knowledge, skills, and abilities that are in the greatest demand in Ukraine and abroad.

The comparison of two training systems on the basis of their generalised content allows us to identify significant differences. First of all, in Polish universities, students have more possibilities for critical thinking skills development than in Ukrainian universities. Thus, it would be advisable to adopt some approaches, activities, and subjects in the national system of education. Due to this reason, training of future language scholars needs to be aimed at processing, estimating, and categorising information. Students should acquire adaptable skills they can apply in all fields of life. Thus teaching in higher educational institutions, universities should not be limited by the theoretical presentation of the ideas and facts; they should teach students how to adopt these skills in their real life.

\section{Conclusions}

Our work has led us to conclude that the study of the positive pedagogical experience of other countries is an important direction and mechanism of improvement of the Ukrainian system of higher education. The results of the analysis of two systems of language scholars training allow determining specific recommendations (for universities and teachers) for improving the quality of critical thinking development during their training at Ukrainian universities. The universities may propose students to follow webinars and online training on critical thinking development, organise the dissemination events among students from different universities or faculties (where they can share their experience in critical thinking skill 
development). Teachers may accomplish their theoretical disciplines with assignments aimed at synthesis and analysis of data; introduce project-based learning that required gathering and analysis of information; involve students to participate in brainstorming activities (for example, set a task to give five ways of critical thinking skills enhancement), etc. Considerable progress has been made with regard to the ways of critical thinking enhancement during the training of future language scholars.

At the current stage of development of higher educational standard and Professional standard in Ukraine, developing curricula for language scholars training, it is necessary to consider the specificities of their $21^{\text {st }}$ century skills development, namely 4 Cs: collaboration, communication, critical thinking, and creativity.

The present study has only examined the ways of critical skills enhancement in future language scholars during training. Therefore, this study has not taken into consideration the level of development in the rest of the core skills (4 Cs).

Future studies on the current topic are therefore required the investigation of cross-disciplinary skills assessment of future language scholars in order to elaboration efficient and gradual assessment of the $21^{\text {st }}$ century skills.

\section{Acknowledgements}

This research was supported by the Department of English Language for Humanities and Faculty of Linguistics, Igor Sikorsky Kyiv Polytechnic Institute and the Department of Pedagogy and Psychology of Professional Education, National Aviation University, Ukraine.

We gratefully acknowledge the help provided by Prof. Liliya Morska and The University of BielskoBiala, Bielsko-Biala, Poland in the analysis of interviews and language portfolios of Polish students.

\section{References:}

Baranovska, L. \& Zasluzhena, A. (2015). Content peculiarities of Bachelors' in English language and literature training at universities of Switzerland. Comparative Professional Pedagogy, 5(1), 46-51. https://doi.org/10.1515/rpp-2015-0020

Belghiti, K., Allame, E., Mohamed, Y. \& Mohamed, C. (2017). Critical Thinking Development: The Case of the English Course in the CPGE Classes in Meknes, Fes and Kenitra. Arab World English Journal. http://dx.doi.org/10.2139/ssrn.2895544

Bowell, T. \& Kemp, G. (2010). Critical thinking. A coincide guide ( $3^{\text {rd }}$ Ed.), Routledge.

Bransford, J. D., Brown, A. L. \& Cocking, R. R. (2000). How People Learn: Brain, Mind, Experience, and School: Expanded Edition. National academy press: Washington, D.C.

Carol, A., Blohm, S. \& Urdan, T. (2004). Assessing Secondary Students' Disposition toward Critical Thinking: Development of the California Measure of Mental Motivation. Educational and Psychological Measurement, 64 (2). https://doi.org/10.1177/0013164403258464

Cohen, E. D. (2009). Critical thinking unleashed. Rowman \& Littlefield Publishers, Inc.

Evens, M., Verburgh, A. \& Elen, J. (2014). The development of critical thinking in professional and academic bachelor programmes. Canadian Center of Science and Education. Higher Education Studies, 4 (2), 42-51. https://doi.org/10.5539/hes.v4n2p42

Ennis, R. (2015). Critical thinking. A streamlined Conception. In M. Davies et al. (eds.), The Palgrave Handbook of Critical Thinking in Higher Education (pp 31-47). New York: Palgrave Macmillan. https://doi.org/10.1057/9781137378057_2

Facione, P. (1990). Critical Thinking: A Statement of Expert Consensus for Purposes of Educational Assessment and Instruction (The Delphi Report). Retrieved March, 242020 from https://philpapers.org/archive/FACCTA.pdf

Hutterli, S. (ed.). (2012). Coordination of Language Teaching in Switzerland. Current Status - Developments - Future Prospects. Bern: General Secretariat EDK. Retrieved from http://edudoc.ch/record/106283/files/Stub34E e.pdf.

Kuchay, O. (2016). Theoretical and methodological principles of future primary school teachers training in higher educational institutions of Poland by means of multimedia technologies [Teoretychni i metodycgni zasady pidgotovky maibutnich uchyteliv pochankovych klasiv u vycshyh navchalnych zakladah Polschi zasobamy multymediynych technologii]. Unpublished PhD thesis, The Bohdan Khmelnytsky National University of Cherkasy, Cherkasy, Ukraine.

Manzon, M. (2011). Comparative Education: The Construction of a Field. Dordrecht \& Hong Kong: Springer \& Comparative Education Research Center, The University of Hong Kong.

Matthews, R. \& Lally, J. (2010). The Thinking Teacher's Toolkit. Critical Thinking, Thinking Skills and Global Perspectives. Continuum International Publishing Group.

Morska, L. (2018). Teaching intercultural communicative competence: theoretical background. Ars linguodidacticae (Mystestvo lingvodydaktyky), 2 (1), 12-18. https://doi.org/10.17721/2663-0303.2018.2.02

Mukan, N. (2011). Professional Development of Secondary School Teachers in Continuing Teaching Education Systems of the United Kingdom, Canada, USA. [Profesiyny rozvytok uchyteliv zagalnoosvitnich schkil Velykoi Brytanii, Kanady, SSCHA]. Unpublished PhD thesis, Lvivska Polytechnika, Lviv, Ukraine.

National Research Council (2012). Education for Life and Work: Developing Transferable Knowledge and Skills in the 21st century. Washington, DC: The National Academies Press. https://doi.org/10.17226/13398.

Preparing $21^{\text {st }}$ Century Students for a Global Society: An Educator's Guide to the "Four Cs" (2016). National Education Association. Retrieved March 24, 2020 from http://www.nea.org/assets/docs/A-Guide-to-Four-Cs.pdf

Radchenko, T. (2014). Multicultural fundamentals of organisation of studies at universities of Switzerland [Multykulturni zasady organizatsii navchannya v universytetach Schveitsarii]. Unpublished PhD thesis, Zhytomyr State Ivan Franko University, Zhytomyr, Ukraine.

Rutherford, A. (2019). The Systems Thinker - Analytical Skills: Level Up Your Decision Making, Problem Solving, and Deduction Skills. Notice the Details Others Miss. (The Systems Thinker Series Book 2). 
Samoilov, A. (2014). Development of Secondary School Students Critical Thinking as a Strategic Priority of Modern Education: Goals, Objectives and Outcomes. Journal of Siberian Federal University. Humanities \& Social Sciences, 12 (7), 2021 2033. Retrieved March, 242020 from http://journal.sfu-kras.ru/en/number/16564

Simkova, I. \& Tuliakova, K. (2020). The implementation of spoken interaction methods as efficient tools to improve 21 st century skills in English for specific purposes training in Higher schools of Ukraine. Revista Dilemas Contemporáneos: Educación, Política y Valores, 7(2). Retrieved March, 242020 from https://www.dilemascontemporaneoseducacionpoliticayvalores.com

Solodikhina, M. \& Solodikhina, A. (2019). Development of critical thinking of master's degree students using STEM cases. The Education and Science Journal, 21 (3), 125-153. https://doi.org/10.17853/1994-5639-2019-3-125-153

Sysoieva, S. (2008). Development of Comparative professional education in Ukraine: educological context. Educology, 7, 49-58. https://doi.org/10.28925/2226-3012.2018.7.4958

Stone, H. J. S. (1981). The Common and the Diverse: a Profile of Comparative Education. Johannesburg, McGraw-Hill.

Vasyliuk, A. (2011). Trends in the reform of school education in Poland (XX-early XXI) [Tendentsii reformuvannia shkilnoi osvity Polshchi (XX - pochatok XXI st.)]. Unpublished PhD thesis, Ternopil, Ukraine.

Wolhuter, C., Popov, N., Manson, M., \& Leutwyler, B. (2008). Comparative Education at Universities World Wide. Sofa, Bulgaria: Bureau for Educational Services.

Wolhuter, C. (2016). Jullien: Founding Father of Comparative and International Education Still Pointing the Way. Education Provision to Every One: Comparing Perspectives from Around the World, BCES Conference Book, 14(1), 19-24. Retrieved March, 24, 2020 from http://bces-conference-books.org/onewebmedia/2016.1.019-024.Charl.Wolhuter.pdf

Zapalska, A., Michael, M., McCarty, D., Young-McLear, K. \& White, J. (2018). Design of assignments using the 21st century bloom's revised taxonomy model for development of critical thinking skills. Problems and Perspectives in Management, 16 (2), 291-305. https://doi.org/10.21511/ppm.16(2).2018.27

Zasluzhena, A. (2016). The Concept of English Philologists' Training at Swiss Universities. Comparative professional pedagogy, 6(2), 88-95. https://doi.org/10.1515/rpp-2016-0024 